\title{
Concepts in community care for people with a learning difficulty
}

Edited by

P. Brigden \& $M$. Todd

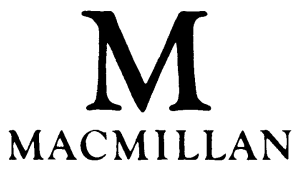


(C) The contributors 1993

All rights reserved. No reproduction, copy or transmission of this publication may be made without written permission.

No paragraph of this publication may be reproduced, copied or transmitted save with written permission or in accordance with the provisions of the Copyright, Designs and Patents Act 1988, or under the terms of any licence permitting limited copying issued by the Copyright Licensing Agency, 90 Tottenham Court Road, London W1P 9HE.

Any person who does any unauthorised act in relation to this publication may be liable to criminal prosecution and civil claims for damages.

First published 1993 by

THE MACMILLAN PRESS LTD

Houndmills, Basingstoke, Hampshire RG21 2XS

and London

Companies and representatives

throughout the world

ISBN 978-0-333-57246-7

DOI 10.1007/978-1-349-12863-1

A catalogue record for this book is available from the British Library 


\section{Contents}

List of contributors

Introduction

Julia Lloyd

1 Social policy: a perspective on service developments and inter-agency working

Steven Rose

2 Quality issues

Patricia Brigden and Margaret Todd

3 Planning and managing change Patricia Brigden

4 Advocacy Jo Young

5 Personal relationships Patricia Brigden

6 Integrated leisure opportunities Steven Rose

7 Psychotherapeutic approaches with people with learning difficulties

Tony Taylor

8 A systematic approach to care Tony Gilbert

9 Therapy in relation to people with learning difficulties Heather Yule, Frances Loydd and Caroline Carter 
iv - Contents

10 Medical needs in a service for people with learning difficulties

Rosemary Baker

11 Education and training

Margaret Todd

12 Summary

Margaret Todd

Index 


\section{Contributors}

Rosemary A. Baker MB, ChB, MRCGP, MRC Psych.

Consultant Psychiatrist in Mental Handicap, Priority Service Unit, Basingstoke, Hampshire

Patricia Brigden BSc, Dip. Clin. Psych., C. Psychol., Dip. Man. (OU)

Consultant Clinical Psychologist, East Berks Trust for People with Learning Difficulties, Bracknell, Berkshire

Caroline Carter BSc, MCSLT

Senior Speech and Language Therapist for people with learning difficulties, Priority Service Unit, Basingstoke, Hampshire

Tony Gilbert RNMH, BSc

Staff Development Officer, Tatchbury Mount Hospital, Southampton, Hampshire

Frances Loydd Dip. COT

Senior Occupational Therapist for people with learning difficulties and coordinator of a service for people with head injury, Priority Service Unit, Basingstoke, Hampshire

Julia Lloyd BSc, Dip. Clin. Psych.

Senior Clinical Psychologist, Priority Service Unit, Basingstoke, Hampshire

Steven Rose MSc, RNMH, RMN

Executive Director, Southwark Consortium for People with Learning Difficulties, Southwark, London

Tony Taylor RNMH, RMN, Qualified Psychotherapist

Locality manager and nurse psychotherapist for people with learning difficulties, Priority Service Unit, Basingstoke, Hampshire 
vi $\cdot$ Contributors

Margaret Todd RNMH, RMN, RGN, Dip. N. (Lond.), FETC

Staff Development Manager, Priority Service Unit, Basingstoke, Hampshire

Jo Young RNMH

Clinical service manager for people with learning difficulties, Priority Service Unit, Basingstoke, Hampshire

Heather Yule BA, MCFP

Manager of physiotherapy services for people with learning difficulties, Priority Service Unit, Basingstoke, Hampshire 